\title{
Open Online Assessment Management System Platform and Instrument to Enhance the Information, Media, and ICT Literacy Skills of $21^{\text {st }}$ Century Learners
}

\author{
https://doi.org/10.3991/ijet.v14i07.9953 \\ Jintavee Khlaisang ${ }^{(凶)}$, Prakob Koraneekij \\ Chulalongkorn University, Bangkok, Thailand \\ jintavee.meg.chula.edu
}

\begin{abstract}
Information literacy (IL), media literacy (ML), and information communication and technology literacy (ICT Literacy: ICTL) are some of the most important skills for 21 st century learning and which help promote other skills, including life and career skills and learning and innovation skills. This kind of learning allows students to connect as a learning network without barriers or borders. It fully supports the use of equipment and technology to develop the skills necessary for life. The purpose of this research study is two-fold: first, to develop a research-based Open Online Assessment Management System (OOAMS), and second to develop the standardized measurement for an assessment of IL, ML, and ICTL for higher education learners. The sample group consists of 2,300 higher education learners and the methodology was divided into 3 phases: (1) developing the conceptual framework, definition, and features of IL, ML, and ICTL for higher education learners; (2) examining requirements, designing wireframes, and developing an OOAMS for higher education students; and (3) testing the quality of OOAMS for IL, ML, and ICTL using exploratory factor analysis (EFA) and confirmation factor analysis (CFA) statistical methods. The research result found that, first, the specific features of the system included development using PHP and MySQL database and the design to interact with users with a responsive UI framework. The system is compatible with MOOCs and the Open edX platform, or can be used as a stand-alone application. It can create, share, copy, and extend both Likert scales and rubrics evaluation forms. It can also generate reports in both CSV and PDF formats. Secondly, the results of this research provided a standardized measurement for assessing IL (49 items), ML (63 items), and ICTL (69 items). Also, it can be improved or enhanced for online learning in a ubiquitous learning context such as e-learning, blended learning, virtual learning and MOOCs effectively.
\end{abstract}

Keywords-Assessment Management System, information literacy, media literacy, information communication and technology literacy

\section{Introduction}

Higher education institutions around the world have set the guidelines for elearning and MOOCs. Research has investigated the acceptance of e-learning and 
MOOCs, as well as the design of e-learning and MOOCs to suit students and the context of each institute [1][2][3][4][5]. A challenge of online instruction has been identified as measurement and evaluation, which is an important component in learning that results in an effective learning process [6]. The change in instruction has made digital literacy increasingly important. Many organization have defined and provided the scope of the term 'digital literacy'. The report on 'Towards a national digital skills framework for Irish higher education' defines 'digital competency' as a combination of concepts, including information literacy, media literacy and information and communication technology (ICT) literacy. This is in line with the definition of digital literacy provided by the Partnership for $21^{\text {st }}$ Century Skills organization in 2007 which has become widely accepted as one of the development frameworks in the $21^{\text {st }}$ century. The organization advocates and encourages education institutes around the world to incorporate these skills into the educational system. In doing so, this will prepare students to acquire knowledge and skills beyond purely academic applications, including learning and innovation skills, information skills, media and technology skills, as well as life and career skills. Learners can apply and adapt their knowledge and skills to the situation creatively while studying, and after graduation, to the world of work effectively and productively for life [3] [7] [8] [9] [10]. In India, digital instruction has been developed to address the diversity of learners in different areas, using mobile technology adapted for remote areas, context enabled curriculum, along with flexible learning schedules. The results of the interviews showed that $90 \%$ of the learners who participated became more confident in using computers and the internet [11]. In Australia, instruction for media literacy and social understanding has been provided through Minecraft. Learning evaluation was conducted in media literacy across four nodes: digital materials, media production, conceptual understanding and media analysis [12]. Digital literacy assessment was done by online data collection through Moodle, self-assessment via Google Forms, and SPSS [13]. There are two types of evaluation and data collection to develop digital literacy framework. The first comprises multiple-choice measurement, Likert scale measurement, and short-answer questions. The second comprises the semi-structured interview [14].

In response to the importance of these issues, Massive Open Online Courses (MOOCs) have played an important role in teaching and learning that promotes lifelong learning, such as edX, Coursera, Udacity, Udemy, P2Pu and Khan Academy. In Thailand, Thai MOOCs have been developed using Open edX, the open source MOOC platform founded in 2012 by Harvard and MIT, as the main platform. Then, Open edX was released as code-sharing software for MOOCs. At present, several educational institutes around the world have installed Open edX for MOOC instruction. For example, edX (https://www.edx.org) has 10,000,000 students. As for Thai MOOC, there are currently more than 65,000 registered users with over 100,000 registered uses. However, the Open edX platform is still limited in terms of measurement as students can only be assessed by quiz.

In order to meet the educational needs of digital learners and the direction of international education with its focus on creating innovators, measurement should be improved to cover both traditional assessment and authentic assessment. It should focus on the well-rounded measurement of knowledge, attitudes, and skills. To be in line 
with the concept of open learning and open content, there should be public spaces for exchanging, sharing, adjusting, and extending the evaluation form for instructors who teach similar subjects for the utmost benefit of the measurement. Therefore, this research has developed a research-based Open Online Assessment Management System (OOAMS) an Open edX extension system. It can be used, improved, and extended not only for MOOC, but also as a standalone system for other types of online instructions including e-learning, and blended learning effectively. This has produced MOOC instruction that is complete in terms of learning management, content, and measurement. This research also developed a standardized test that was accepted by using advanced research statistics analysis to test online measurement in accordance with the definition and attributes of those skills. This can be measured accurately and reliably. There are three sets of measurements: (1) information literacy (IL), (2) media literacy (ML), and (3) ICT literacy (ICTL). Both results of the research can help drive higher education institutions to raise teaching and learning to their full potential.

\subsection{Research questions}

- What areas do the conceptual framework, definition, and features of information literacy (IL), media literacy (ML), and ICT literacy (ICTL) for higher education learners cover?

- What are the specific features of Open Online Assessment Management System (OOAMS) and the evaluation criteria of IL, ML, and ICTL for higher education learners in OOAMS?

- What are the results of the quality testing of online assessment of IL, ML, and ICTL? What are the specific features of the measurement of IL, ML, and ICTL?

\section{Methodology}

The research was divided into 3 phases based on the research questions.

Phase 1: Development of the conceptual framework, definition, and features of IL, ML, and ICTL for higher education learners by studying the ideas, theories, and research relating to IL, ML, and ICTL for higher education learners to develop the conceptual framework, definition, and features of IL, ML, and ICTL for higher education learners. Then, experts checked the content validity, and the content was revised according to their suggestions.

Phase 2: Development of the online assessment system, the OOAMS, of IL, ML, and ICTL for higher education learners. This is an innovation designed and developed based on the research. There are two specific features:

- The specific features of the system

- The specific features of the measurement

This paper focuses on the specific features of the measurement.

Three initial measurements were developed and published. The three sets of measurements were standardized using advanced research statistics analysis as follows: 
- IL

- ML

- ICTL

These comprise one of four important skills for $21^{\text {st }}$ century learning. The system publishes the measurements for students in the above-mentioned three areas.

Phase 3: Testing of the quality of the OOAMS by testing the three measurements with a sample group of 2,300 higher education learners through three various means. The first was through an online test via an online assessment system $(n=150)$ to test the quality of each item of the measurement using the item total correlation (IOC) method and selecting items with IOC above .20 . The second $(n=150)$ tested the initial quality of each item of the measurement by finding the correlation between the score of an item and the total score of each area of the measurement (IOC) and conducting an initial reliability test with Cronbach's alpha coefficient. The third tested higher education learners $(\mathrm{n}=1,000)$. The data was analyzed by exploratory factor analysis (EFA). Then the three measurements were tested again $(\mathrm{n}=1,000)$ using confirmation factor analysis (CFA).

\section{$3 \quad$ Results}

In the following section, the research findings are aligned with the research questions as follows.

\subsection{The result of the development of the research-based assessment system}

The result of the development of the research-based assessment system and online rubric that provides testing and evaluation for higher education learners is that it is compatible with the Open edX platform. The system is compatible with the MOOCs Open edX platform or can be used as a stand-alone application.

As mentioned above, the result of this research proves that the OOAMS system has two specific features:

- The specific features of the system

- The specific features of the measurement

The layout of the system was used to develop the system with the following features:

- An evaluation creation system for an Open edX platform which is compatible with the Open edX platform and that can also be used as a stand-alone application;

- The system can create, share, copy or extend an evaluation form with both Likert scales and rubrics, which instructors can apply to other subjects;

- It can be used for traditional assessment and authentic assessment for selfassessment, peer assessment, and instructor assessment; 
- It was developed with PHP and MySQL databases and a user interface was designed with the responsive UI framework; and

- It can generate reports in both CSV and PDF formats [3].

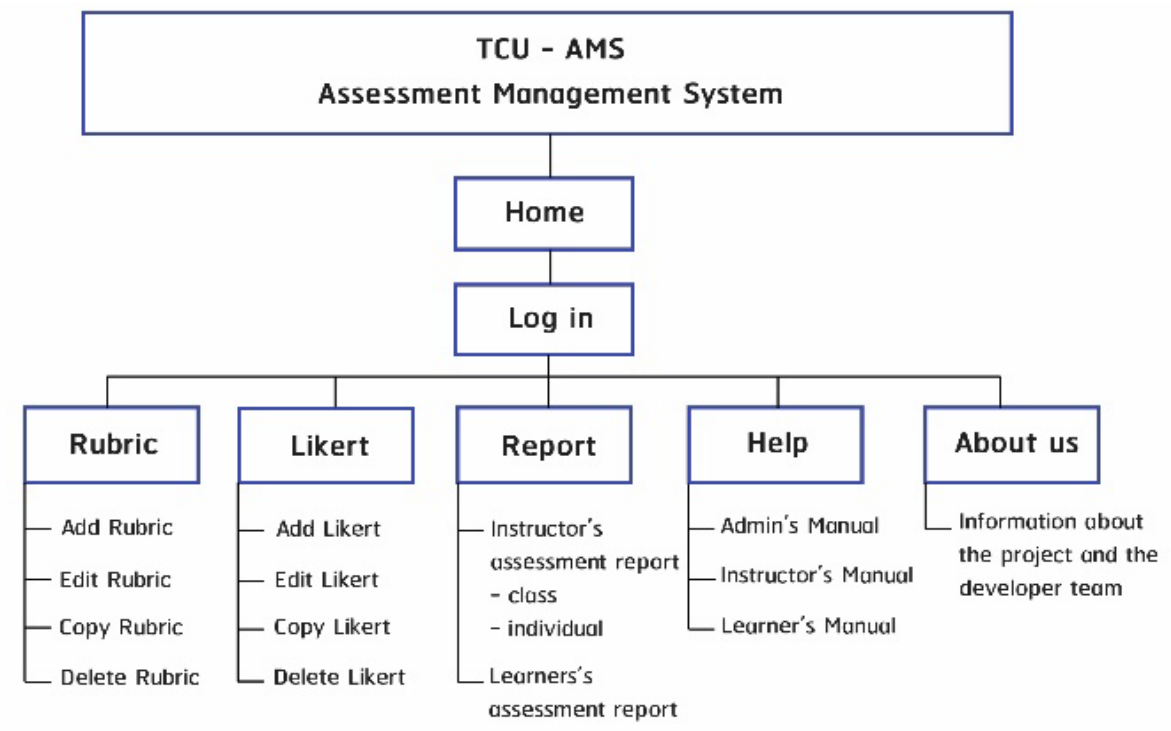

Fig. 1. Layout of OOAMS, referred to as TCU-AMS

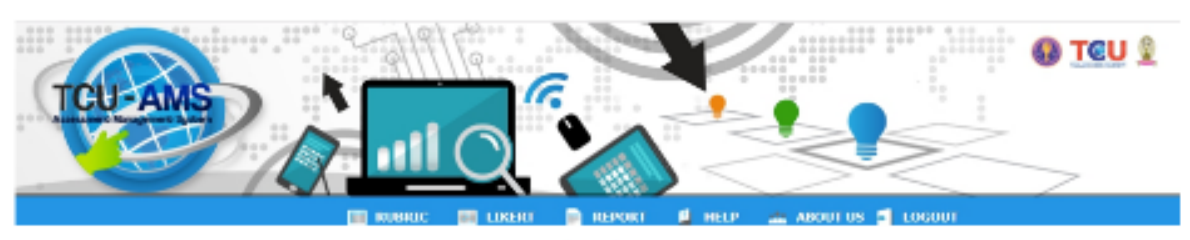

Rubric

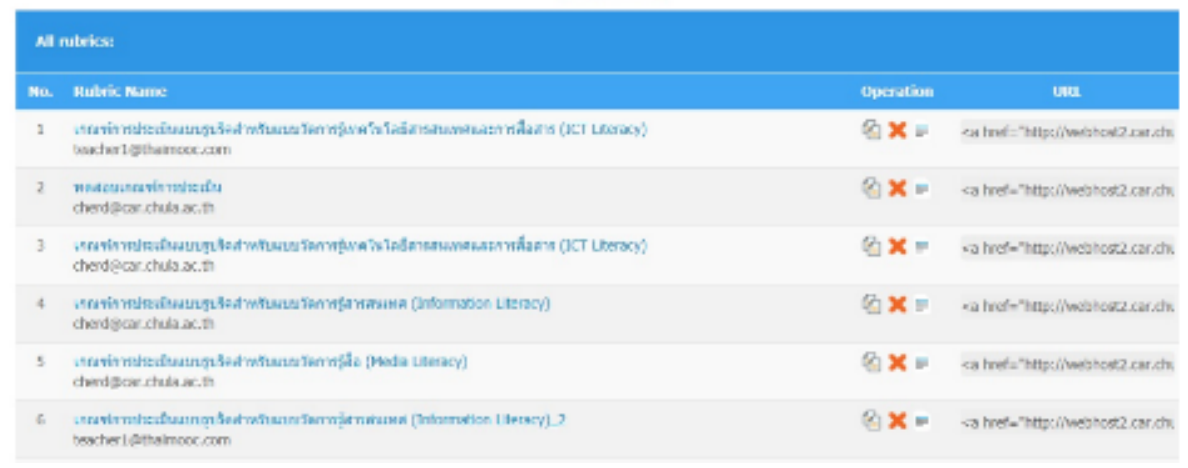

Fig. 2. Special features of the system that can create, modify, share, copy, and extend Likert scale and rubric evaluation forms 

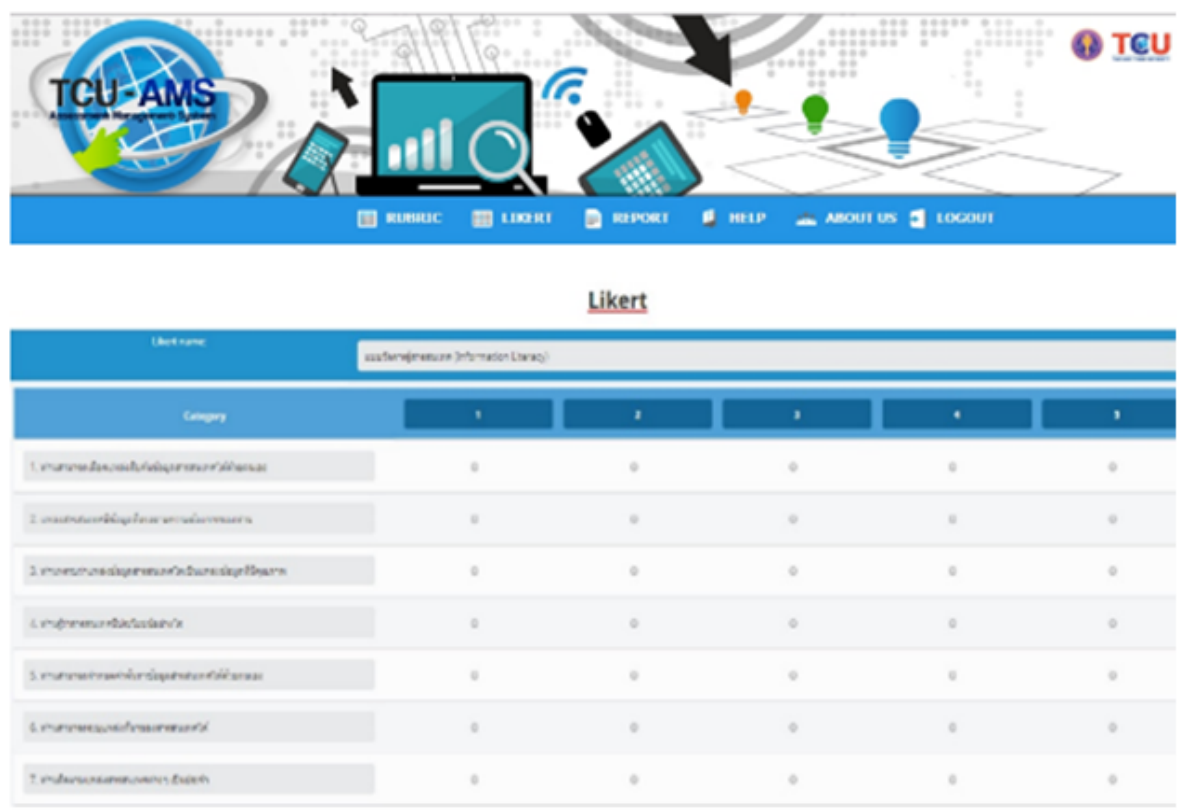

Fig. 3. TCU-AMS (Likert page)

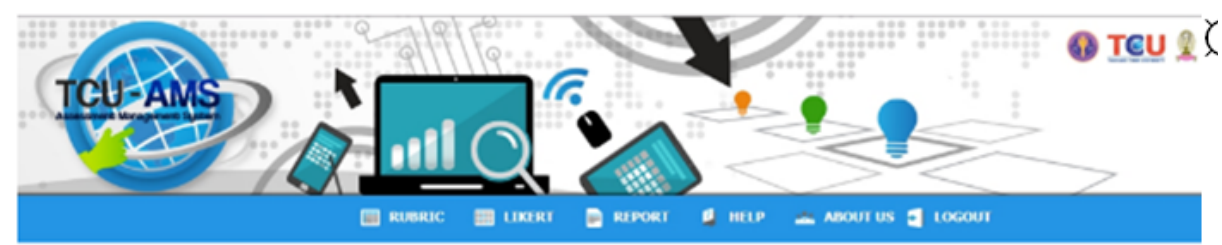

Rubric

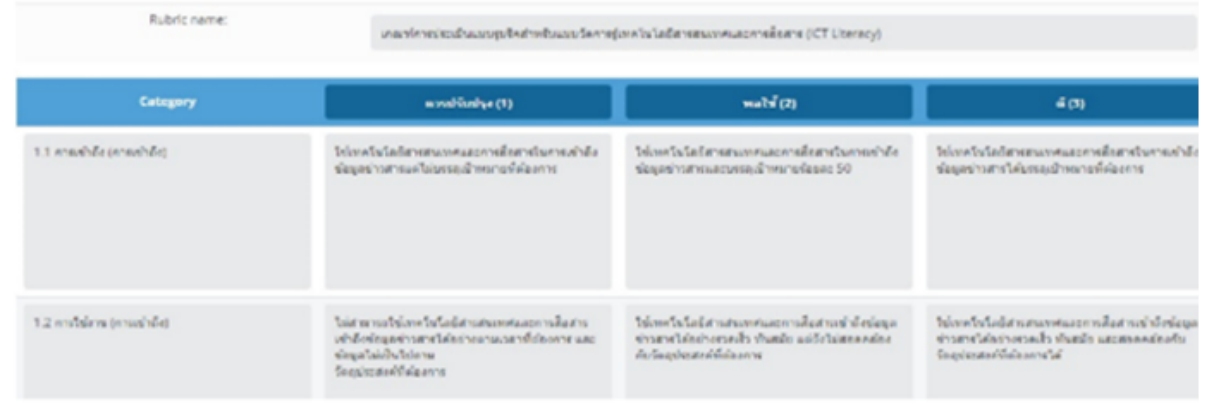

Fig. 4. TCU-AMS (Rubric page) 


\subsection{The results of the development of an online research-based standardized test on the IL, ML, and ICTL for higher education learners}

This paper focuses on the specific features of the measurement. The three sets of measurements have been developed and published. These are standardized by using advance research statistics analysis. The measurements comprise:

- Information literacy

- Media literacy

- ICT literacy which constitute one of four key areas for $21^{\text {st }}$ century learning

The system publishes the measurements that assess students in three dimensions. These were developed from the conceptual framework, definition, and features of information literacy, media literacy and information and communication technology literacy for higher education learners. The consistency and definition of the $21^{\text {st }}$ century skills on information literacy was validated by the experts, with the media tested on 2,300 learners. The definition, scope, features of information literacy, media literacy, and ICT literacy for higher education learners were found to be appropriate. The criteria of behavior level are:

- Means having the behavior/ability as stated in the question at the lowest level

- Means having the behavior/ability as stated in the question at a low level

- Having the behavior/ability as stated in the question at a medium level

- Having the behavior/ability as stated in the question at a high level, and 5 having the behavior/ability as stated in the question at the highest level.

Table 1. Information Literacy : Definition, scope, and measurement

\begin{tabular}{|c|c|}
\hline \multicolumn{2}{|c|}{ Information Literacy (49 items) } \\
\hline Definition: & 1. You can select the information source by yourself. \\
\hline $\begin{array}{l}\text { Level of knowledge and understanding in } \\
\text { using existing information accurately and that }\end{array}$ & $\begin{array}{l}\text { 2. You can set the searching words for information by } \\
\text { yourself. }\end{array}$ \\
\hline matches the needs. [15] [16] [17] & 3. You regularly keep up to date on the information \\
\hline Scope: & source. \\
\hline Important features: & 4. You can classify the type of information source. \\
\hline $\begin{array}{l}\text { (1) Ability to identify the needs for infor- } \\
\text { mation }\end{array}$ & $\begin{array}{l}\text { 5. You set the method before searching for infor- } \\
\text { mation. }\end{array}$ \\
\hline (6 items) & 6. You set the period for searching for information. \\
\hline (2) Ability to access information (3 items) & 7. You understand the components of the information \\
\hline (3) Ability to manage information ( 9 items) & source. \\
\hline (4) Ability to apply & 8. You perform the search according to the goal. \\
\hline information ( 6 items) & 9. You consider the information you receive before \\
\hline (5) Ability to have ethics in & using it. \\
\hline (13 items) & rganize the informatior \\
\hline Rating Scale: & 11. You consider the information you receive before \\
\hline Ability Level & trusting it. \\
\hline Higher than 246 Highest & 12. You can explain the difference between infor- \\
\hline 209-245 High & mation sources. \\
\hline 168-208 Medium & 13. You can evaluate the value of each type of infor- \\
\hline 131-167 Low & mation source. \\
\hline Lower than 130 Lowest & $\begin{array}{l}\text { 14. You can analyze the good and bad effects of } \\
\text { information. }\end{array}$ \\
\hline
\end{tabular}




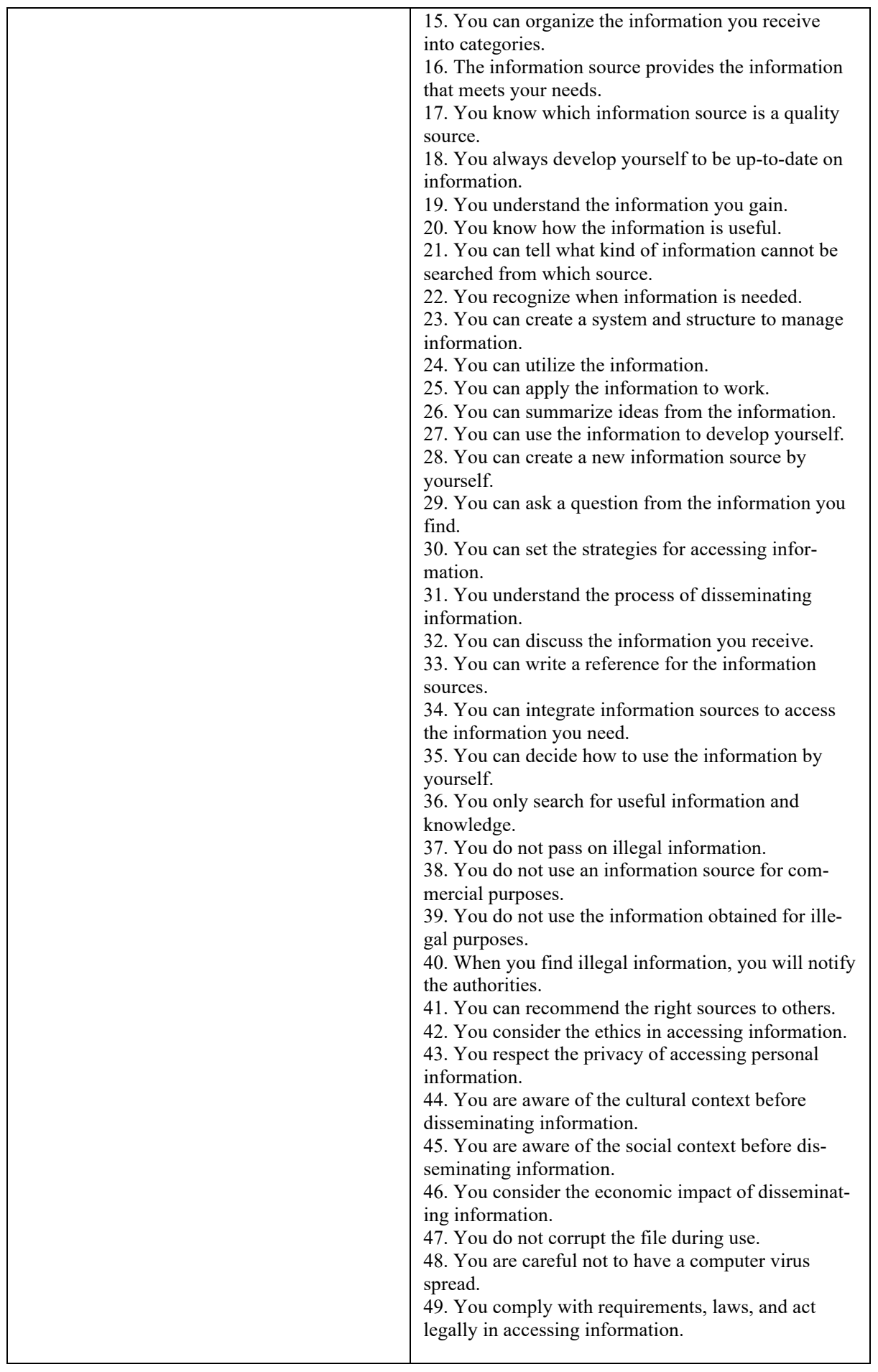


Table 2. Media Literacy: Definition, scope, and measurement

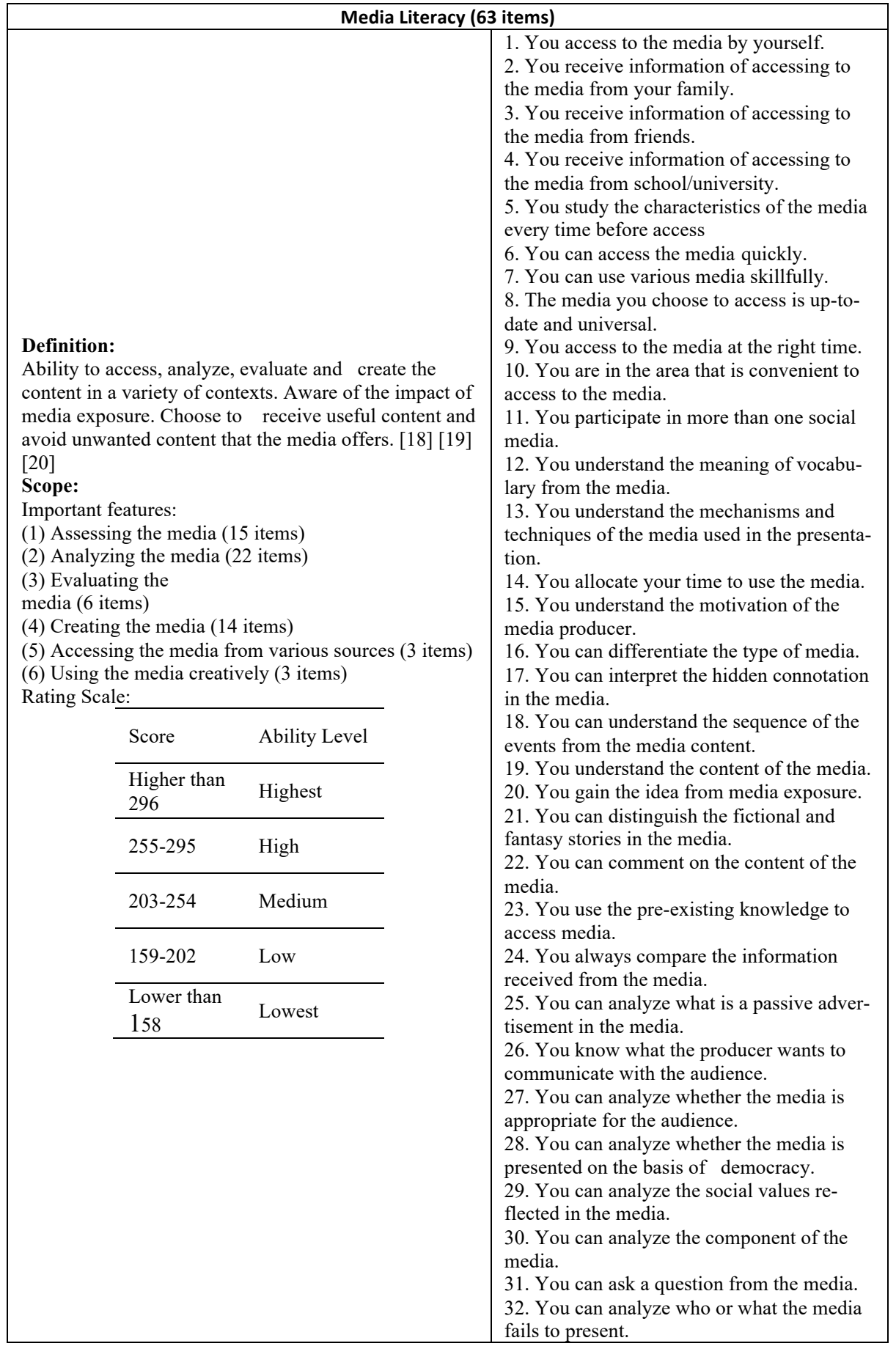




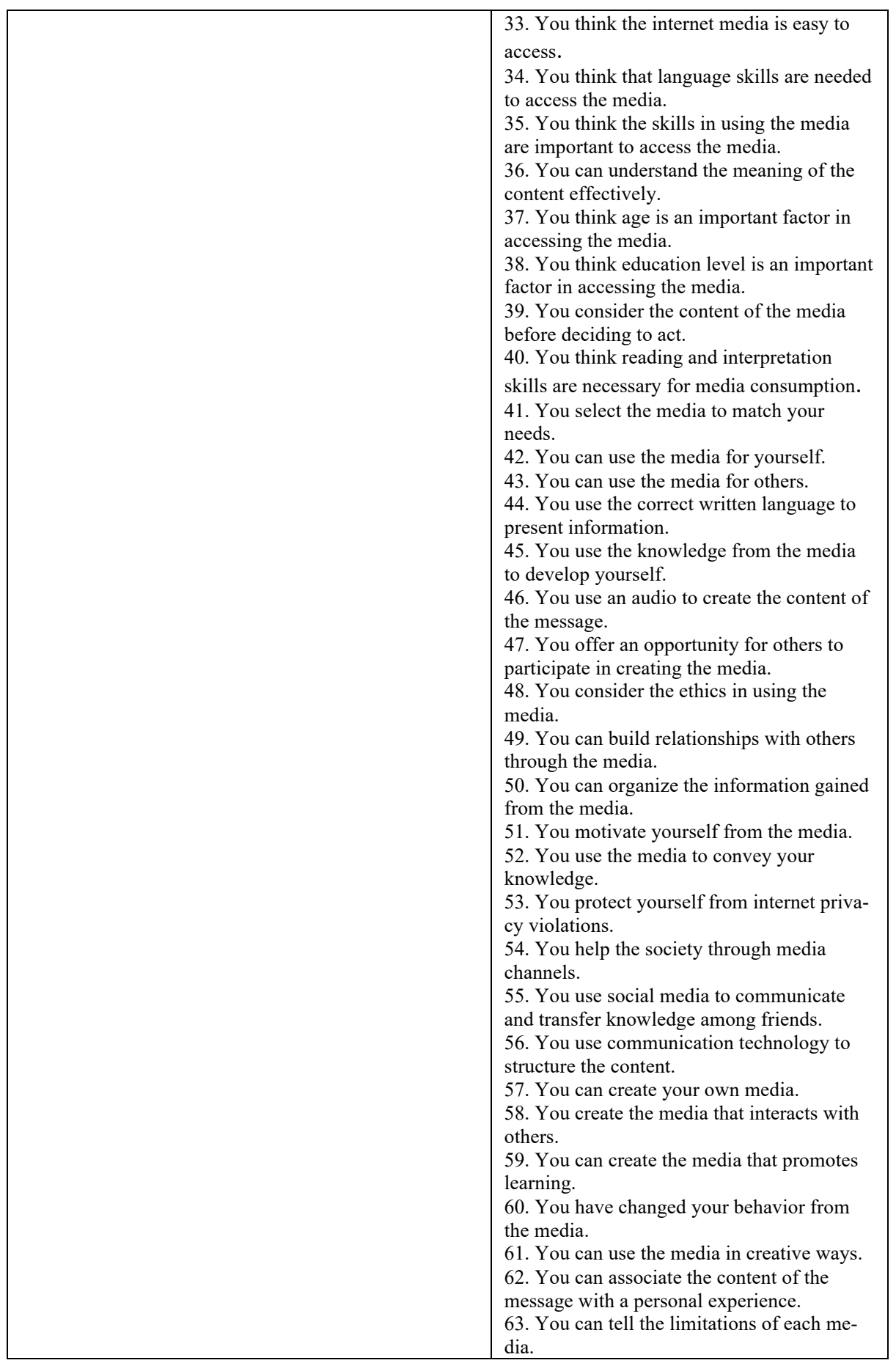


Table 3. ICT Literacy: Definition, scope, and measurement

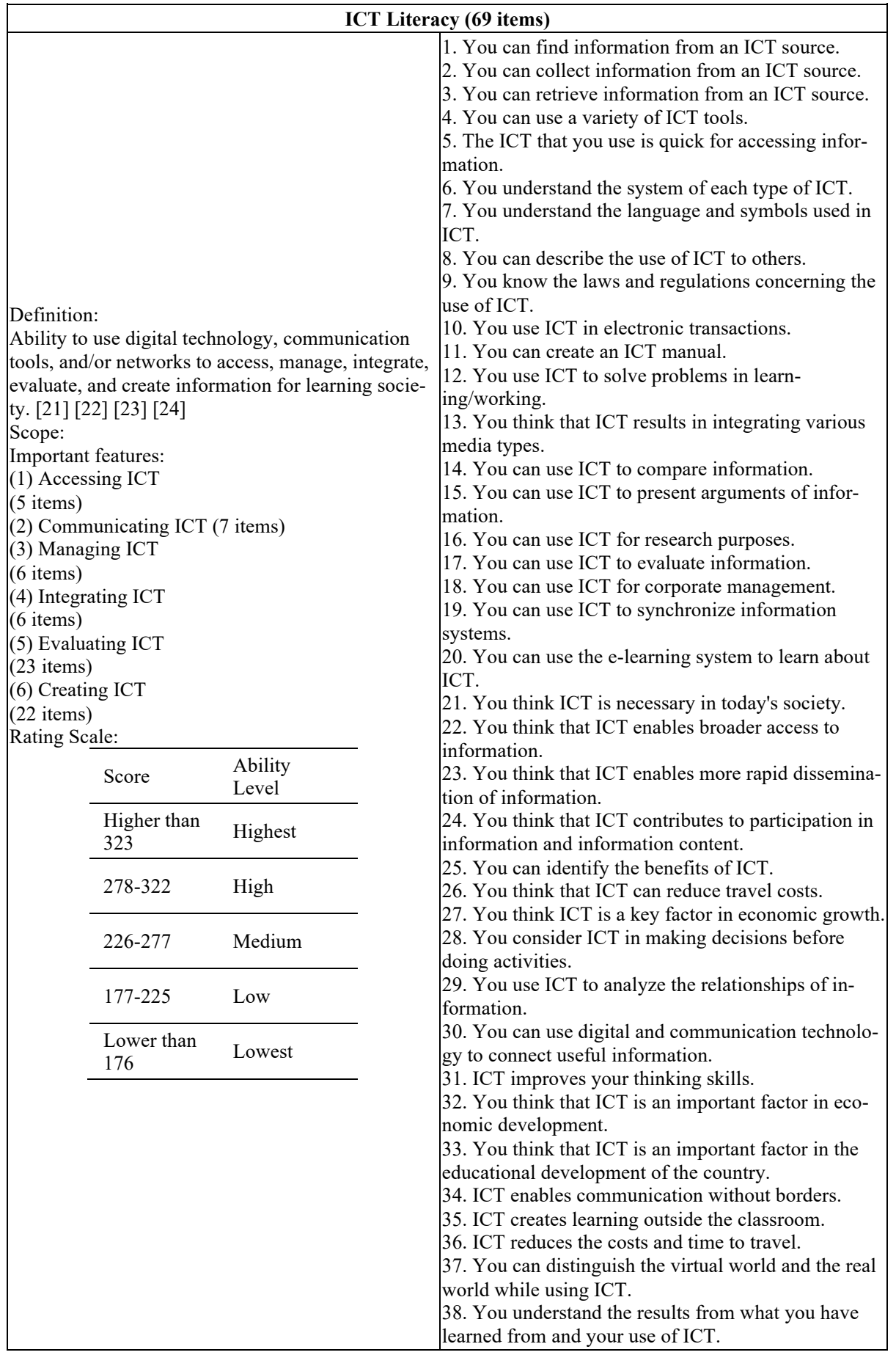


ICT Literacy (69 items)

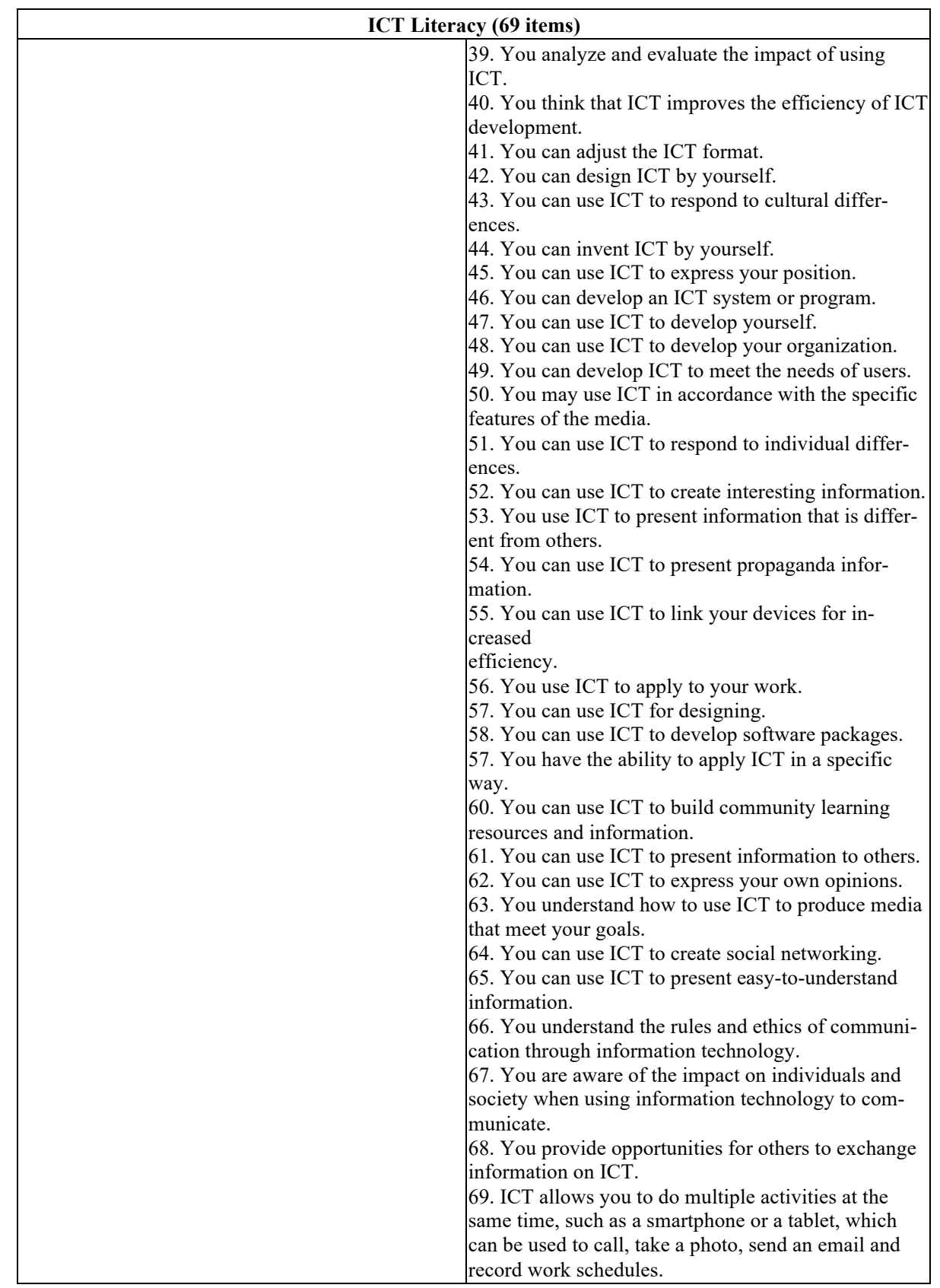


The measurement method of the three tests comprises the following:

- Determining the date and time to measure information literacy, media literacy, and information and communication technology literacy for higher education learners,

- Preparing the measurement via an online system,

- Learners must study the test guidelines and test method to take the test correct ly,

- Taking an online test, and

- Collecting and interpreting the score.

\section{Discussion}

It can be seen that at present several organizations in many countries have focused on information literacy, media literacy and ICT literacy, and have developed a learning framework to develop these skills [11] [12] [14]. However, there is still a lack of a standardized test, especially for an online assessment system, which is compatible with Moodle LMS and Open edX platform used in MOOCs. Previous studies have designed assessment systems in Moodle platforms [13]. However, the assessment criteria are not compatible for both platforms. This study realized the importance of designing the measurement for current use in various online learning systems. The developed system can be used as an add-on to Open EDX and stand-alone applications.

The results of this research support the idea that an online assessment system is an important component of online teaching and learning. It can evaluate and return immediate results. Thus, it reduces the burden on the instructor. The system can create a variety of question types. It is a great challenge to create an assessment tool other than the traditional multiple-choice questions and one that can score automatically [3] [25] [26]. This is in accordance with [27] who studied online self-assessment system, which helped learners to learn better compared to offline assessment, which requires substantial time to prepare a test and analyze the results. The online test system plays an important role in helping learners get automatic scores and recommendations. In addition, the system supports the different levels of learning among the learners. The development of current technology helps to create a learning system and test that is suitable for each student. The results of the test can be evaluated and results compared immediately [28].

In addition, relevant research developed a test system for online learning that is consistent with this research. For example, the study of the development of an online assessment system by using an interactive test found that the test can evaluate a learner's real ability. The system has a special feature that enables the user to edit the test, test the system, automatically grade the score, share a template and test. This allows instructors to develop and use the test according to their needs and context [29]. One study looked at a web-based adaptive testing system to classify the learning ability of students. 
The system consists of:

- An administrator mode for organizing test items, student information and instructor information,

- An instructor mode for student management and analyzing test trends

- A student mode for an online test and reporting the results [30].

As regards the consistency and benefits of the system development and standardized test, research has focused on the measurement of knowledge and skills in digital literacy. Self-assessment enables learners to become aware of their efficacy in a concrete and specific context [31]. The rubric-based model emphasizes the assessment of real conditions. The results show that the rubrics are a useful assessment and can identify potential learners to promote self-efficacy and self-development. This is because the criteria are clearly described and this helps to understand the behavior and ability in each dimension [32].

\section{Conclusion}

This research was developed in accordance with the $21^{\text {st }}$ century educational framework of information literacy (IL), media literacy (ML) and ICT literacy (ICTL) in the online learning context. This is an important foundation for learning management at the present. The results of this research are divided into two main areas:

- The development of a research-based Open Online Assessment Management System (OOAMS). It can provide a test and evaluation for higher education learners. It is compatible with Open edX platform, which is a popular open source MOOC platform for higher education institutions around the world. Since it is an open source system, users can add or modify the source code according to the needs of each organization. It can also be used as a stand-alone system for other forms of online instruction

- The development of a research-based online-standardized test on IL, ML, and ICTL for higher education learners.

This is very useful in learning management in higher education. The suggestion for future research is to study the development of this assessment system by enhancing the effectiveness in processing and displaying learning results in a concrete and dynamic way to create a challenging learning process.

\section{Acknowledgement}

This paper was based on the research study titled "Development of Online Testing and Rubric Scoring System for Information, Media, and ICT Literacies for Higher Education Learners" which was conducted by the authors of this paper during 20162017. The research was first published at the $10^{\text {th }}$ International Conference on Education and New Learning Technologies (2018). This research paper has added and fo- 
cused on the results of the final stage to provide a more useful and concrete insight for further usage. The authors would like to express our sincere appreciation to the Thailand Cyber University Project, the Office of Higher Education Commission, Ministry of Education in supporting this research study. Our appreciation also extends to Educational Invention and Innovation research unit, the experts and subjects involved in the study for their advice and support. The authors hope that the findings in this research can be expanded to and widely used in ICT utilization in HEIs.

\section{$7 \quad$ References}

[1] Christensen, C. M., and Eyring, H. J. (2011). The innovative university: Changing the DNA of higher education from the inside out. Forum for the Future of Higher Education, 47-53.

[2] Guo, Y., Zhang, M., Bonk, C.J., and Li, Y. (2015). Chinese Faculty Members' Open Educational Resources (OER) Usage Status and the Barriers to OER Development and Usage. International Journal of Emerging Technologies in Learning. 10(5): 59-65. https://doi.org/10.3991/ijet.v10i5.4819

[3] Khlaisang, J. and Koraneekij, P. (2018). Development and Validation of the Online Assessment Management System for 21st Century Learners. Proceeding of the 10th International Conference on Education and New Learning Technologies, Palma De Mallorca, Spain, JULY 2018. https://doi.org/10.21125/edulearn.2018.0977

[4] Miller, J.L. (2015). Educational Technology Bridging the Gap Between Youth and Adult Learners of the 21st Century. Adult Education Research Conference.

[5] Khlaisang, J. and Likhitdamrongkiat, M. (2015). E-Learning System in Blended Learning Environment to Enhance Cognitive Skills for Learners in Higher Education. Procedia - Social and Behavioral Sciences, 174, 759-767. https://doi.org/10.1016/j.sbspro.2015.01.612

[6] Khlaisang, J. and Koraneekit, P. (2015). Outcome-based Learning Plugins System in Blended Learning Environment for Higher Education Learners. Funded by Office of Higher Education Commission Fiscal Year 2015.

[7] All Aboard: Digital Skills in Higher Education. Retrieved from http://www.allaboardhe.ie. [7 July 2017].

[8] Partnership for 21st Century Skills (2011). 21st Century Skills. Retrieved from http://www.p21.org. [7 July 2017].

[9] Moto, S., Ratanaolarn, T., Tuntiwongwanich, S., Pimdee, P. (2018). A Thai Junior High School Students' 21st Century Information Literacy, Media Literacy, and ICT Literacy Skills Factor Analysis. International Journal of Emerging Technologies in Learning, 13(9), 87-106. https://doi.org/10.3991/ijet.v13i09.8355

[10] Khlaisang, J., Mingsiritham, K. (2016). Engaging virtual learning environment system to enhance communication and collaboration skills among ASEAN higher education learners. International Journal of Emerging Technologies in Learning, 11(4), 103-113. https://doi.org/10.3991/ijet.v11i04.5503

[11] Prema P., Nedungadi, R. M., Georg G., Lynnea E., Raghu R., (2018). Towards an inclusive digital literacy framework for digital India, Education + Training, 60(6), 516-528. https://doi.org/10.1108/ET-03-2018-0061 https://doi.org/10.1108/ET-03-2018-0061

[12] Dezuanni,M. (2018). Minecraft and children's digital making: implications for media literacy education, Learning, Media and Technology, 43:3, 236-249, DOI: 10.1080/17439884.2018.1472607 https://doi.org/10.1080/17439884.2018.1472607 
[13] Porat, E., Blau, I., and Barak, A. (2018). Measuring digital literacies: Junior high-school students' perceived competencies versus actual performance. Computers \& Education. 126 (November 2018), 23-36. https://doi.org/10.1016/j.compedu.2018.06.030

[14] Wray, C.C. and Mulvihill, R. (2018). Framing Up Digital Literacy: Reviewing and Reframing Information Literacy Modules, The Reference Librarian, 59:4, 195-204, DOI: 10.1080/02763877.2018.1498431 https://doi.org/10.1080/02763877.2018.1498431

[15] Association of College and Research Libraries. (2000). Competency standards for

[16] [1] higher education standards, Performance indicator information literacy and outcomes. Retrieved November 19, 2016, from http://www.ala.org/acrl/ilstandardlo.htm.

[17] Swain, M., Sundre, D. L. and Clarke, K. (2014). The Information Literacy Test (ILT) Test Manual. Madison Assessment, Harrisburg, VA 22807.

[18] Bundy, A. (2004). Australian and New Zealand Information Literacy Framework.

[19] [2](2nd Edition). Library Publications University of South Australia. Retrieved November 20, 2016, from http://www.anziil.org/index.htm

[20] European Association for Viewers' Interests. (2014). Expert in Media Literacy and Digital. Education Brussels Area, Belgium.

[21] The London School of Economics and Political Science. (2004). Media literacy and the challenge of new information and communication technologies Invited for The Communication Review. Houghton Street, London, WC2A 2AE, UK.

[22] Austrian Federal Ministry of Education and Women's Affairs. (2014). Assessing Media Literacy Levels in Europe and the EC Pilot Initiative. Paolo Celot, EAVI Brussels.

[23] California Emerging Technology Fund (KEMPSTER Group). (2008). California ICT Digital. Literacy Assessments and Curriculum Framework. Retrieved November 15, 2016, from http://www.ictliteracy.info/rf.pdf/California\%20ICT\%20Assessments\%20

[24] [3]and\%20Curriculum\%20Framework.pdf

[25] The International ICT Literacy Panel. (2007). Digital Transformation A Framework for ICT Literacy. Educational Testing Service.

[26] Khalkhali, A, Moradi S., and Amuei, F. (2008). Assessment and Comparison of ICT'

[27] Literacy between Teachers and Students in Iran's Secondary Schools. World Applied Sciences Journal, 4(3), 396-405.

[28] Katz, I. R. and Macklin, A. S. (2007). Information and Communication Technology (ICT) Literacy: Integration and Assessment in Higher Education. Retrieved November 15, 2010, from http://www.iiisci.org/Journal/CV\$/sci/pdfs/p890541.pdf

[29] Stratling, R. (2017). The Complementary use of audience response systems and online tests to implement repeat testing: A case study, British Journal of Educational Technology, 48(2), 370-384. https://doi.org/10.1111/bjet.12362

[30] Thompson, M. M., and Braude, E. J. (2016). Evaluation of Knowla:An Online Assessment and Learning Tool. Journal of Educational Computing Research, 54(4), 483-512. https://doi.org/10.1177/0735633115621923

[31] Liu, X., Liu, H., Bao, Z., Ju, B., and Wang, Z. (2010). A web-based self-testing system with some features of Web 2.0: Design and primary implementation, Computers \& Education. $55,265-275$.

[32] Shin, S. and Hashimoto, H. (2014). A System for the automatic assembly of test questions using a no-sql database, International Conference of e-Learning 2014.

[33] Koong, C.S. and Wu, C.Y. (2010). An interactive item sharing website for creating and conducting on-line testing. Computers \& Education. 55, 131-144. https://doi.org/10. $\underline{\text { 1016/j.compedu.2009.12.010 }}$ 
[34] Lee, J., Park, S., and Kim, K. (2012). Web-based adaptive testing system (WATS) for classifying students' academic ability. Turkish online Journal of Distance Education, 13(4), 2535 .

[35] Rosman, T., Mayer, A.K., and Krampen, G. (2015). Combining self-assessments and achievement tests in information literacy assessment: empirical results and recommendations for practice. Assessment \& Evaluation in Higher Education, 40(5), pp. 740-754. https://doi.org/10.1080/02602938.2014.950554

[36] Edwards, F. (2017). A rubric to track the development of secondary preservice and novice teachers' summative assessment literacy, Assessment in Education: Principles, Policy \& Practice, 24(2), 205-227. https://doi.org/10.1080/0969594X.2016.1245651

\section{Authors}

Jintavee Khlaisang is an Associate Professor at the Department of Educational Technology and Communications, and a member of Educational Invention and Innovation research unit, Faculty of Education, Chulalongkorn University, Bangkok, Thailand. Her research interests include E-learning, Flipped classroom, Blended Learning Environment, Virtual Learning Environment, Ubiquitous Learning, and MOOCs (jintavee.m@g.chula.edu).

Prakob Koraneekij is an Associate Professor at the Department of Educational Technology and Communications, and a member of Educational Invention and Innovation research unit, Faculty of Education, Chulalongkorn University, Bangkok, Thailand. His research interests include E-portfolio, E-learning, Mobile Learning, Blended Learning Environment, and MOOCs (prakob.k@chula.ac.th).

Article submitted 2018-12-02. Resubmitted 2019-01-15. Final acceptance 2019-01-16. Final version published as submitted by the authors. 